\title{
Pothur Sreenivasulu (1950-2020): a humble virologist who made eminent contributions to virology discipline in India
}

\author{
${\text { Hema } \operatorname{Masarapu}^{1} \cdot \text { P. Lava } \operatorname{Kumar}^{2}\left(\text { D) } \text { Satyanarayana Tatineni }^{3} \cdot \text { D. V. R. Reddy }\right.}^{4,5}$
}

Received: 13 September 2020/ Accepted: 19 October 2020

(C) Indian Virological Society 2020

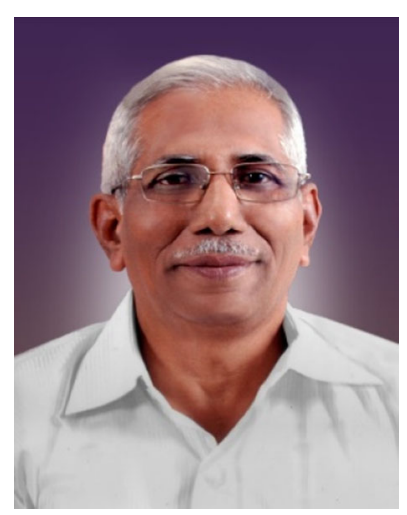

Plant virology lost an outstanding scientist and an eminent teacher with the sudden demise of Prof. Pothur Sreenivasulu (hear afterward, Sreenivasulu) on 19th August 2020 in Bangalore. We lost a mentor and a most trustworthy friend. He was known for his pioneering contributions to the characterization of viruses infecting groundnut, sugarcane, sorghum, rice, banana, pigeonpea, vegetable and aroid crop

D. V. R. Reddy: Former Principal Virologist.

P. Lava Kumar

L.Kumar@cgiar.org

1 Department of Virology, Sri Venkateswara University, Tirupati, Andhra Pradesh, India

2 International Institute of Tropical Agriculture (IITA), Oyo Road, Ibadan, Nigeria

3 USDA-ARS, University of Nebraska-Lincoln, Lincoln, NE, USA

4 International Crops Research Institute for the Semi-Arid Tropics (ICRISAT), Patancheru, Hyderabad, India

5 Present Address: Banjara Hills, Hyderabad, Telangana, India plants in India, and development of diagnostic tools for their detection based on serological and nucleic acid properties. As a co-founder, he made immense contributions to the Department of Virology's growth at Sri Venkateswara University (SVU), Tirupati, Andhra Pradesh, India. Several of his students have become renowned scientists around the world. The first three co-authors of this contribution were his students, and the last author was his mentor for postdoctoral research.

Sreenivasulu was born in Thagguparthy village in Anantapur District, Andhra Pradesh, on 1st June 1950. He was awarded Konri Venkatagiri and Srimathi Ganjam Venkata Ramanaiah memorial prizes for obtaining the first rank in his M.Sc. degree, indicating his brilliance and interest in higher education. He earned a Ph.D. degree in plant virology in 1978 from SVU under the guidance of Prof. M. V. Nayudu. He was a recipient of the Council of Scientific and Industrial Research (CSIR), New Delhi Junior-, Senior and Postdoctoral Research fellowships (JRF/SRF/PDF).

Sreenivasulu had spent his entire career at the SVU. He was appointed as a lecturer in the Department of Botany in 1979. Subsequently, sustained efforts by him and Prof. M. V. Nayudu resulted in the establishment of the Virology department with University Grants Commission (UGC) recognition to offer M.Sc. and Ph.D. programs at SVU in 1987, first of its kind in India. Prof. Sreenivasulu made significant contributions to the design of the virology course curriculum on par with international standards. It was the first and only department in SVU to offer an interdisciplinary post-graduate (PG) program in a semester system during that time.

Sreenivasulu became a Reader and, in 1994, became a Professor of Virology. He became Head of the Department of Virology (1990-1992; 1994-2005); and served as Chair 
of the Board of Studies (BOS) from 1994 till his superannuation in 2010. He was also the founding coordinator for M.Sc. Biotechnology (1995-1996), Microbiology courses (2000-2006), and ad hoc chairman of the BOS (2000-2005) of Microbiology at SVU. He has served as an external member of BOS in Microbiology and Biotechnology PG courses and external subject experts of faculty selection committees of several south Indian Universities. He taught multiple subjects and was known for broad subject knowledge, punctuality, discipline, and excellent teaching and mentoring skills. He held such important positions in SVU as Vice-Principal (2006-2007) and Principal of the College of Biological and Earth Sciences (2007-2009). During his tenure as Principal, he introduced many academic refinements for the welfare of students and faculty.

Sreenivasulu started his virology research on the characterization of groundnut viruses in 1979 when none of India's widely distributed viruses were characterized. His research laid the foundation for subsequent characterization of economically important groundnut viruses by scientists at ICRISAT (International Crops Research Institute for the Semi-Arid Tropics). He worked eighteen months as a Visiting Scientist (1987-1988) in Dr. J. W. Demski's laboratory at the University of Georgia (UG), Griffin, GA, USA. While on sabbatical at UG, he has conducted groundnut virus surveys in Georgia State along with the Jim Demski's team and detected tomato spotted wilt tospovirus (TSWV) and three strains of peanut mottle virus (PMV), i.e., PMV-mild (M), PMV-necrosis (N), and PMVchlorosis (C) [6]. This survey and diagnostics demonstrated TSWV as the least prevalent of the viruses detected and PMV-M as widespread viruses in Georgia; he also showed that the PMV-N and PMV-C isolate cause symptoms similar to TSWV, thereby exposed the limitation of symptom-based surveys for virus incidence at that time. A follow-up study focused on the purification and serological characterization of TSWV isolates in the USA [7]. Antibodies produced against the purified TSWV-US isolate failed to detect Indian TSWV isolates reported by Reddy et al. [3]. These studies subsequently lead to the demarcation of Indian TSWV isolates as distinct species, named peanut bud necrosis virus (PBNV). Sreenivasulu's Ph.D. student, Dr. T. Satyanarayana, as part of his PDF studies at ICRISAT with Dr. D. V. R. Reddy (Principal Virologist), sequenced PBNV genomes (S and M segments) and completed the characterization and phylogenetic placement of novel groundnut infecting tospovirus in India [5].

After returning to SVU from the USA, Sreenivasulu devoted a great amount of time on the characterization of several economically important viruses of local and regional importance affecting tobacco, sorghum, maize, sugarcane, rice, banana, chili, brinjal, groundnut, sesame, papaya, black pepper, cardamom, pigeonpea and aroid plants. To accomplish this task, he has established successful collaborations with many institutions within India and abroad, including with ICRISAT, Indian Institute of Science (IISc) in Bangalore, a regional research station in Acharya NG Ranga Agricultural University in Kovvur, Indian Institute of Spices Research in Calicut, Maharashtra Hybrid Seeds Company in Jalna, University of Delhi-South Campus, and virology programs in the USA, UK and Belgium. Some of his notable achievements are on of peanut chlorotic leaf streak caulimovirus-chlorotic vein banding isolate (PCLSV-CVB) [4], cowpea mild mottle carlavirus (CPMMV), sugarcane mosaic potyvirus (SCMV), sugarcane streak mosaic poacevirus (SCSMV), rice tungro virus complex, maize stripe tenuivirus (MSpV), konjac mosaic potyvirus (KoMV) isolates, spathiphyllum chlorotic vein banding potyvirus $(\mathrm{SCVbV})$, banana bract mosaic potyvirus (BBrMV) isolates, peanut stripe potyvirus (PStV), peanut green mosaic potyvirus isolates (PGMV), cucumber mosaic cucumovirus isolates, pegionpea sterility mosaic emaravirus, and Sreenivasulu was a modest, kind-hearted, and fair person. His impeccable integrity and commitment to achieve perfection are commendable.

Sreenivasulu had completed several major research projects in plant virology funded by the Indian Council of Agricultural Research (ICAR), the DBT (India), the United States Department of Agriculture (USDA) PL-480, DFID (in collaboration with ICRISAT). His pioneering works include complete genome sequencing of SCSMV, a distinct virus in the genus Poacevirus of the family Potyviridae, and the generation of SCSMV-free sugarcane plants using tissue culture technologies [1]. He has maintained steadfast collaboration with Dr. D. V. R. Reddy of ICRISAT since 1978 till his retirement in 2010. One of these collaborative works includes the characterization of pigeonpea sterility mosaic virus, performed as part of the Ph.D. research by his student, Dr. P. Lava Kumar, which unraveled the etiology of a most mysterious virus disease [2], and laid the foundation for a new genus, Emaravirus.

Sreenivasulu led the development of diagnostics such as enzyme-linked immunosorbent assay (ELISA) and dotimmunobinding assay using polyclonal antibodies raised against the purified virus, or an E. coli expressed recombinant virus coat protein antigens for the detection of SCSMV, CMV, BBrMV, KoMV, MSpV, and PBNV. Nucleic acid diagnostics such as hybridization methods (PCLSV-CVB, CMV, SCSMV, and RTBV) and various PCR-based tests, including immunocapture RT-PCR and multiplex PCR assays for simultaneous detection of multiple viruses in a single host. The diagnostic tests created opportunities for students and scientists research on virus 
disease surveys, epidemiological studies, and virus disease control.

Sreenivasulu supervised four M.Phil. and 13 Ph.D. students and published more than 120 research papers and book chapters in reputed national and international journals. The guidance and the opportunities he gave to investigate challenging problems helped many of his students establish successful careers in India and abroad. He has made a significant contribution to the release of the textbook "Plant Viruses," written by Prof. M. V. Nayudu, published by Tata McGraw Hill in 2006. He has delivered invited lectures and chaired scientific sessions in various international and national conferences. He has organized UGC/DBT (Department of Biotechnology) sponsored short term training courses and application of virus diagnostics to scientists across the country. The lab manuals prepared for these courses were popular among the trainees. He was one of the prominent resource persons selected to participate in technology transfer courses organized by ICRISAT. He has reviewed research projects on plant viruses submitted to ICAR, UGC, DST, and DBT for funding and peer-reviewed manuscripts for journals such as Current Science, Indian Journal of Virology (presently, Virus Disease), Indian Phytopathology, Indian Journal of Experimental Biology, and others. He was a life member of the Indian Virological Society (IVS). He was considered a role model for his vision, tireless efforts, commitment to quality, and integrity. He was held in high esteem by his collaborators, colleagues, and students.

Sreenivasulu is survived by his wife Hyma Devi, a daughter Hima Bindu, a son Kodanda Pani, and four grandchildren. His entire family ably supported him in his career. As in the case of all four of us, all Sreenivasulu's students, colleagues, and collaborators have fond memories of their time spent with him.

\section{References}

1. Hema M, Joseph J, Gopinath K, Sreenivasulu P, Savithri HS. Molecular characterization and interviral relationships of a flexuous filamentous virus causing mosaic disease of sugarcane in India. Arch Virol. 1999;144:479-90.

2. Kumar PL, Jones AT, Reddy DVR. A novel mite-transmitted virus with a divided RNA genome closely associated with pigeonpea sterility mosaic disease. Phytopathology. 2003;93(1):71-81.

3. Reddy DVR, Satyanarayana T, Dwivedi SL, Ratna AS, Buiel AAM, Ranga Rao GV, Nigam SN, Naidu RA, Hsu HT, Demski JW. Diagnosis and resistance breeding of peanut bud necrosis virus. Acta Hortic. 1996;431:411-4.

4. Satyanarayana T, Broglio E, Sreenivasulu P, Reddy DVR, Nayudu MV. Genome characterization of peanut chlorotic vein banding disease of groundnut (Arachis hypogaea L) in India. Plant Pathol. 1994;44:966-70.

5. Satyanarayana T, Mitchell SE, Reddy DVR, Kresovich S, Jarret R, Naidu RA, Gowda S, Demski JW. The complete nucleotide sequence and genome organization of the M RNA segment of peanut bud necrosis tospovirus and comparison with other tospoviruses. J Gen Virol. 1996;77(9):2347-52.

6. Sreenivasulu P, Demski JW, Reddy DVR, Misari M, Olorunju E, Kuhn CW. Tomato spotted wilt virus (TSWV) and strains of Peanut mottle virus that mimic TSWV symptoms in peanut in Georgia. Plant Dis. 1988;72:546.

7. Sreenivasulu P, Demski JW, Reddy DVR, Naidu RA, Ratna AS. Purification and some serological relationships of tomato spotted wilt virus isolates occurring on peanut (Arachis hypogaea) in the USA. Plant Pathol. 1991;40(4):503-7.

Publisher's Note Springer Nature remains neutral with regard to jurisdictional claims in published maps and institutional affiliations 